\title{
Discourse Patterns of Lessons on Topics Perceived to be Difficult in Biology at Selected Secondary Schools in Luapula Province of Zambia
}

\author{
Kambi Manda ${ }^{1}$, Christopher Haambokoma ${ }^{1}$, Kabunga Nachiyunde ${ }^{1}$ \\ ${ }^{1}$ Mathematics and Science Education Department, University of Zambia, Lusaka, Zambia
}

*Corresponding Author: Kambi Manda, Mathematics and Science Education Department,University of Zambia, Lusaka, Zambia

\begin{abstract}
This paper explores classroom discourse patterns of perceived difficult topics in biology such as classification, mitosis and meiosis at senior secondary level. A collective case study design was used and data were obtained from students and teachers using observation schedules and interview guides. Purposive sampling was used to select the sample from the target population. Data collected were analysed using discourse analysis and thematic analysis. The study found out that three discourse patterns were used during lessons on topics perceived to be difficult. These three discourse patterns include: Pupil to pupil discourse pattern, teacher led discourse pattern and teacher explanation discourse pattern. The choice of discourse patterns by teachers hinged on the following: non availability of teaching aids, desire to cover more content, engagement of pupils in the lesson, need to relate lessons to real life situations, skill in managing groups, pupil participation and need to provide concrete examples. The inappropriate use of the discourse patterns made understanding of stages of cell division and biological names of living organisms difficult to pupils. Some of the recommendations made were that: Teachers should combine the three discourse patterns namely teacher explanation, teacher led and pupil to pupil discourse patterns when teaching biology because these patterns proved effective when used together. Teachers should avoid using one discourse pattern during lessons on topics perceived to be difficult. Workshops and seminars should be organised for teachers to enable them acquire skills of teacher explanation, teacher led and pupil to pupil discourse patterns for teaching biology.
\end{abstract}

Keywords: Discourse pattern, classification, mitosis, meiosis, biological terms, cell division, practical activities.

\section{INTRODUCTION}

Although biology is supposedly the easiest of the science disciplines, research on student learning has shown that even high calibre, high achieving biology students at elite institutions taught by universally admired academics fail to build a scientifically conceptual and contextual foundation in biology. Perhaps because learning, teaching and assessment strategies in the discipline of biology have become ritualised (Ross, 2011). Biology examination papers usually cover a wide range of topics providing for a wide coverage of syllabus content. The papers usually include questions on recall of factual knowledge as well as questions on application and synthesis (CDC, 2000). The performance of candidates in the 3 biology examination papers in Zambia has not been good (ECZ, 2016). This underachievement of pupils in biology is not new. For example Table 1 shows countrywide biology school certificate results for 1992 and 1993

Table1. Countrywide biology school certificate results for 1992 and 1993.

\begin{tabular}{|l|l|l|l|l|l|l|}
\hline Year & 1 and 2 Distinction & 3 and 4 Merit & 5 and 6 Credit & 7 and 8 Pass & 9 fail & Total \\
\hline 1992 & 371 & 2037 & 3404 & 6420 & $6139(33 \%)$ & 18370 \\
\hline 1993 & 510 & 2048 & 3580 & 6811 & $6113(32 \%)$ & 19062 \\
\hline Totals & $881(2.3 \%)$ & $4085(10.9 \%)$ & $6984(18.6 \%)$ & $13231(35 \%)$ & $12252(32.5 \%)$ & 37432 \\
\hline
\end{tabular}

Source: $M O E 1994$

It is clear from Table 1 that $67.5 \%$ of the candidates in the two years given above merely passed or failed biology. While again in 2002 the picture remained the same, $9975(52.5 \%)$ pupils failed biology 
out of a total of 19000 registered candidates. In 2003, 11890 (58\%) pupils failed biology out of a total of 20500 registered candidates (ECZ, 2004). This national picture in terms of pupil performance is similar to what is prevailing in Luapula province of Zambia.

Figure1 shows Luapula province biology school certificate results for 2016.

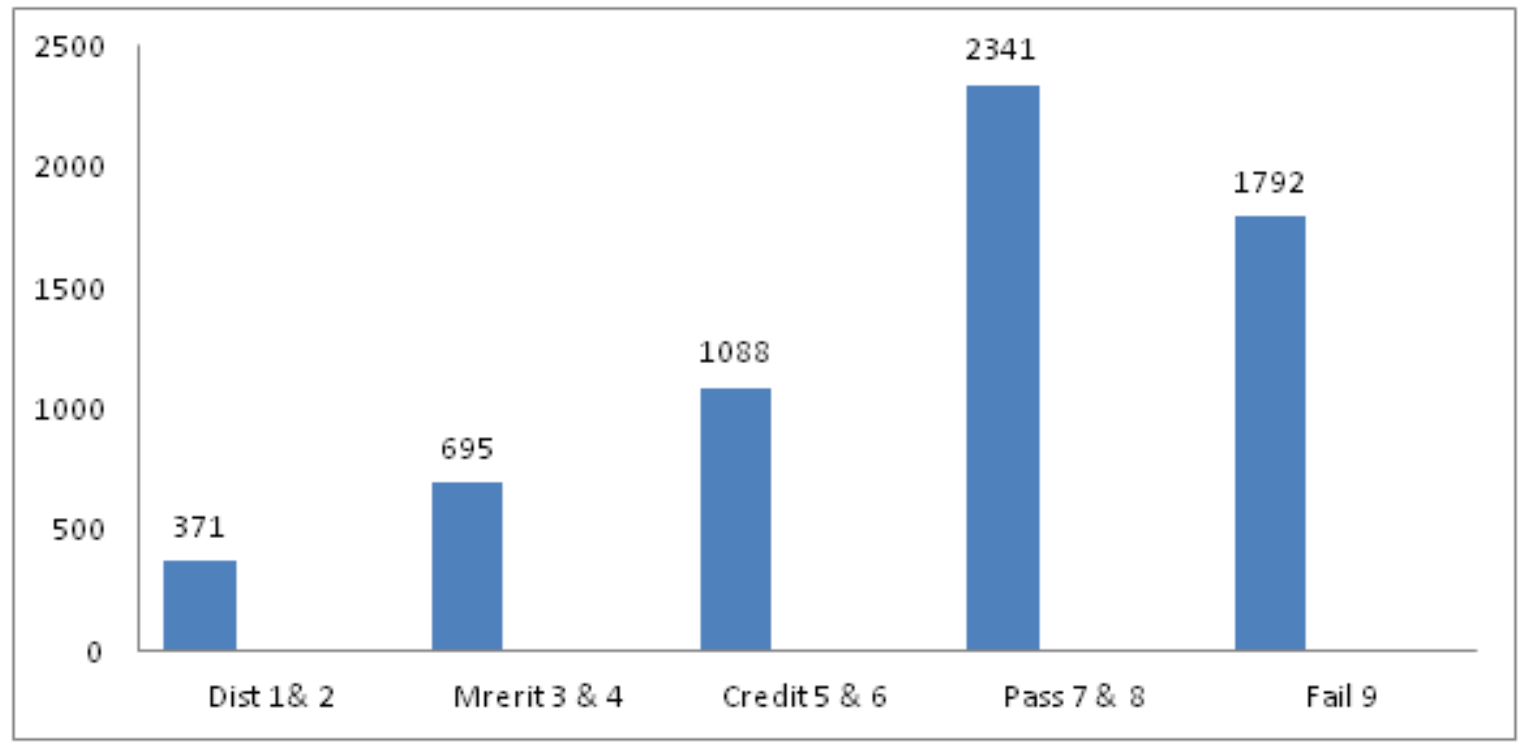

Figure1. School Certificate 2016 biology results for Luapula Province (PEO, Mansa 2017).

As can be seen from Figure 1, 2341 (37.2\%) candidates barely passed and 1792 (28.5\%) candidates failed biology in Luapula Province.

The distressing picture of poor performance in science at school certificate level reflects deficiencies at school level. MoE (1996) identifies the possible deficiency as being in the facilities, the resources or the teaching.

\subsection{Statement of the Problem}

Although researchers (Abimbola, 1998; Haambokoma, 2007; Cimer, 2012; Musonda, 2013; Chocha, Namayanga \& Ndhlovu, 2014, Chifwa, 2015) have identified topics perceived to be difficult in biology, for teachers and learners, no studies have been conducted in Zambia to achieve knowledge and understanding of classroom discourse patterns during biology lessons on these perceived difficult topics in secondary schools in Luapula province. Hence there is no knowledge on this issue of classroom discourse patterns which needs investigation.

\subsection{Purpose of the Study}

The main purpose of this qualitative study was to explore classroom discourse patterns during lessons on topics perceived to be difficult in biology at senior secondary school level in selected secondary schools in Luapula province of Zambia.

\subsection{Research Objectives}

The objectives of the study were as follows:

1. To analyse the classroom discourse patterns during lessons involving topics perceived to be difficult in biology.

2. To investigate how teachers of biology arrive at the choice of discourse patterns they use for teaching topics perceived to be difficult in biology.

3. To assess the effects of discourse patterns used by teachers on pupils' understanding of topics perceived to be difficult in biology.

4. To determine what could be done to improve the teaching and learning of topics perceived to be difficult in biology in order to facilitate pupils' understanding. 


\subsection{Research Questions}

The study was guided by the following questions:

1. How are the classroom discourse patterns like during lessons involving topics perceived to be difficult in biology?

2. How do teachers of biology arrive at the choice of discourse patterns they use for teaching topics perceived to be difficult in biology?

3. What effects do discourse patterns teachers use have on pupils' understanding of perceived difficult topics in biology?

4. What can be done to improve the teaching and learning of topics perceived to be difficult in biology in order to facilitate pupils' understanding?

\section{MeThOdOLOGY}

A qualitative research approach which focused on a collective case study was used in this study to acquire understanding of classroom discourse patterns during lessons involving topics perceived to be difficult.

The study was conducted at 4 secondary schools in Luapula province which had poor school certificate results for 2015 and whose pseudo names and actual school certificate pass percentages are: Mango had 47\%, Orange had 46.6\%, Lemon had 42.8\% and Guava had 41.3\% (PEO Mansa, 2016).

The study population was all senior secondary school pupils learning biology and all teachers of biology.

At each school only 10 pupils were selected to participate in the focus group discussions of the study. This means that a total of 40 pupils participated in the study. A total of 11 teachers were selected from the four schools, three teachers from three schools and two teachers from one school. The sample size is usually small in a qualitative study (Merriam, 1998).

Senior secondary school pupils were selected using purposive sampling. Teachers of biology were selected on the basis of availability and willingness to participate in the study. Eleven Lessons were video recorded and transcribed out of 33 lessons observed which were also purposively sampled.

Semi-structured interview guides and lesson observation schedules were used to collect data

Data collection was preceded by a pilot study at Lubwe secondary school in Samfya District of Luapula Province to check on the suitability of research instruments and data collection procedures.

Trustworthiness was achieved through prolonged field work and recording interviews as well as filming lessons.

Data analysis took place concurrently with data collection as advised by Creswell (2003). Data collected from interviews was analysed using thematic analysis approach (Kombo \& Tromp, 2006). Lesson observations were analysed using discourse analysis (Louis, Lawrence \& Keith, 2000).

Ethical issues were put into consideration such as seeking permission from participants before recording interviews and filming lessons. In addition, actual names of the participants and their schools have not been revealed in the report as recommended by Creswell (2003).

\section{FINDINGS}

Findings of the study are presented according to the research questions. The first part gives the findings on classroom discourse patterns during lessons involving topics perceived to be difficult in biology. The second part analyses the choice of discourse patterns teachers of biology use when teaching topics perceived to be difficult.

\subsection{How are the Classroom Discourse Patterns Like During Lessons Involving Topics Perceived To Be Difficult in Biology?}

From the 11 lessons which were video recorded and transcribed, two lessons were used for this paper, classification of living organisms and mitosis. Below is an excerpt of the lesson introduction on classification of living organisms which took about 10 minutes. 
Teacher: What is classification?

Pupil 1: Classification is an orderly grouping of organisms according to common features

Teacher: To which phylum does an earthworm belong?

Pupil 2: Oligochaeta

Teacher: No

Pupil 3: Nematoda

Teacher: No

Pupil 4: Annelida

Teacher: Yes

The correct answer is Annelida. However, pupils find it confusing to state the correct phylum due to different classes and phyla. The teacher rejected Oligochaeta because this is the class to which earth worms belong. The teacher also rejected Nematoda because this is another phylum where round worms belong.

The teacher explained that there are various ways of classifying organisms. The teacher said that the common system used by biologists is called natural classification, where organisms with similar features are grouped together.

The second lesson was on mitosis and here is an excerpt from the main part of the lesson:

Without the help of any teaching aid or diagrams on the stages of mitosis, the teacher started asking pupils questions on mitosis as follows:

Teacher: What stages are involved in mitosis?

Pupil 4: Interphase

Pupil 5: Anaphase

Pupil 7: Telophase

Pupil 8: Metaphase

The teacher described the process of interphase by saying the cell has its normal structure. This was not clear to the pupils and one pupil asked the teacher to explain clearly what he meant by interphase.

Pupil: What is interphase?

Teacher: This is a stage where the genetical materials are enclosed in the nuclear membrane.

Still this explanation from the teacher was not adequate because pupils did not understand what happens during interphase.

Teacher: What happens during prophase?

Pupil 2: During this stage nuclear membrane disappears

Pupil 3: Centrosomes will form the fibres

Pupil 4: Centrosomes move to the poles

The teacher did not clarify any of the answers coming from the pupils concerning the process of prophase. The teacher did not explain clearly what was meant by interphase because he only said that during interphase the cell has its normal structure. This made one pupil to seek clarification from the teacher on the process of interphase. The teacher's explanation this time around did not satisfy the pupils because he said that interphase is when the genetical materials are enclosed in the nuclear membrane thereby not explaining what happens during interphase.

\subsection{Findings on the Choice of Discourse Patterns}

3.2.1. How do teachers of biology arrive at the choice of discourse patterns they use for teaching topics perceived to be difficult in biology?

The choice of discourse patterns for teachers of biology normally depends on the teacher's experience, interest, ability and the intelligence level of the class he is teaching. Since the approach to the teaching of science and methods to be used depend on various circumstances, the teacher of 
science should study these factors and choose a particular way of teaching which his experience convinces him to be best suited for the particular situation.

\subsubsection{Non Availability of Teaching and Learning Materials}

One of the reasons which teachers of biology were giving for the choice of discourse patterns they used was non availability of teaching and learning materials. One teacher had this to say;

I had difficulties in accessing teaching aids such as videos, which I should have used to show the pupils on mitosis.

\subsubsection{Desire to Cover More Content}

Another reason reported for the choice of discourse pattern was the amount of work to be covered. A large amount of scientific content can be presented to pupils through a discourse pattern which involves teachers giving out information to pupils who are expected to merely listen, therefore a wide syllabus can be covered within a stipulated time. This was also observed by one teacher who said that;

I used the lecture method to save on my time. I covered a lot of content in 80 minutes which was not going to be possible if I had used group work.

Another teacher had this to say:

I did not use the question answer method for a long time because pupils were taking time to answer questions so I opted to start explaining most of the time to try and cover a lot of items.

Moreover, the nature of content sometimes determines the method of teaching to be used. In fact, the lecture method is used to introduce a new a topic or unfamiliar content. This was pointed out by one teacher who said that;

The lecture method was appropriate for this topic because the content was very new to the pupils. I was going to waste pupils' time if I had used group work because pupils were not going to find answers easily.

\subsubsection{Engagement of Pupils in Lesson}

The choice of discourse pattern also depends on whether the pupils will be engaged in the lesson or not. This was mentioned by one teacher who said that;

Pupils follow properly if they are actively involved in the lesson

The teacher should acknowledge the pupils by involving them in the discussion this is usually done when the teacher draws a good number of pupils into a discussion and prevents brighter pupils from monopolising the discussion.

\subsubsection{Need to Relate Lessons to Real Life Situations}

Some teachers decide on the discourse pattern to use when they want pupils to appreciate the link between lessons and real life situations. One teacher had this to say;

I wanted them to appreciate how the knowledge obtained from classification can be useful in their lives.

Pupils appreciate very much lessons which are linked to their real life situations. This is normally achieved when teachers give real life examples during lessons.

\subsubsection{Skill in Managing Groups}

In most cases teachers use discourse patterns they are very conversant with. One teacher was asked why he used the pupil to pupil discourse pattern during the lesson on mitosis he said that;

I had very good understanding of how to manage pupils in groups and how to make group work successful.

Teachers tend to use discourse patterns they are familiar with so that they are able to resolve conflicts and misunderstandings easily. 


\subsubsection{Pupil participation}

Reluctant participants also make teachers decide on the use of group work because they rarely speak though they may be listening. Therefore in order to involve them in the lesson teachers try to use stronger pupils to help weaker pupils. This came out from one teacher who said that;

I think I used group work to make each and every learner to participate and those who are slow learners to be helped by fellow pupils.

In this case the teacher should even stop dominating participants from consuming much air time by talking too much.

When a lot of pupils are not involved in the lesson some teachers try to use classroom discussions to involve them in the lesson. This was observed by one teacher who said that;

Not all the pupils were involved in the lesson as a result I came up with class discussion instead of group discussion.

In this case the teacher directs the discussion by pointing at each and every pupil in the class to participate.

\subsubsection{Need to Provide Concrete Examples}

Some teachers decide to use charts because they believe that there pupils are not good at reading and that it is difficult to make sense out of words on the stages of mitosis. One teacher had this to say;

I experienced challenges because pupils do not know how to read, meiosis is very difficult for pupils to understand that is why I brought out the pictures for the pupils to see.

Certain pupils tend to make words from pictures, therefore it is important that stages of mitosis are first shown to pupils in form of diagrams before describing them using words.

A good number of teachers brought out a lot of real specimens during classification of living organisms in order to make the lessons realistic. Thiswas also mentioned by one teacher who said that;

I wanted to make the lesson more realistic, if pupils see the organisms they were going to appreciate the lesson very much.

When pupils are shown real specimens during lessons on classification of living organisms which they can see with their eyes and verify they tend to enjoy the lessons very much.

\subsubsection{Laziness}

Some pupils thought that their teachers choose certain ways of teaching due to laziness. One pupil had this to say;

Whenever the teacher gives us group work then he has nothing to teach us, he even goes out of the classroom to talk to his friends, we just remain without any guidance on how to go about the work as a result we just start making noise.

This is particularly true because some teachers did not even have lesson plans and they just introduced the lessons and went on to divide their classes into groups which they did not even monitor.

\subsection{What Effects do these Discourse Patterns Teachers use have on Pupils' Understanding of Perceived Difficult Topics in Biology?}

Discourse patterns which teachers use when teaching topics perceived to be difficult in biology have positive as well as negative effects on pupil understanding.

\subsubsection{Inappropriate Group Activities}

Group work is normally used by teachers when delivering their lessons on mitosis and meiosis. However, groups can degenerate into off-task or social conversations as was reported by one pupil who said that:

We finished our work within two minutes and started doing other things like charting. Others were busy reading other books in our group which were not related to what we were doing. 
This is particularly true because when group members lose track of the meetings purpose, discussions often wander off in many directions at once.

Teachers often give inappropriate group activities to pupils. This was also observed by one pupil who said that;

We did not know what was supposed to be done as a result we just started copying from the textbook.

The problem here is that the group has trouble starting and ending, making decisions, moving on, reaching consensus and staying on the task. One possible explanation is that the group is unclear or overwhelmed by the task given to them by the teacher.

\subsubsection{Mastery of Work}

Discussions in groups also help some pupils to master the work easily. Pupils develop their understanding through listening to peers. This was shown by one pupil who said that;

I will be able to understand if my fellow pupil explains to me. There were a lot of new terms coming from the teacher, so I did not understand anything I am just waiting for some of my friends who understood the topic to explain to me.

Group work helps the most able students to support those who are less able than themselves. Group work also helps learners to develop their verbal skills in reasoning and justification.

\subsubsection{Mind Capturing Introductions}

Good introductions tend to capture the minds of pupils. One pupil had this to say:

I was able to follow the lesson properly because the introduction captured my attention.

This was also supported by another pupil who said that:

The introduction of the lesson was interesting and the explanations were clear.

For introductions to be interesting teachers must strive to show pupils different types of teaching aids. This was reported by one pupil who said that:

During the introduction the teacher brought different plants small and big and we got very interested in the lesson.

\subsubsection{Positive Effects of Group Work}

Pupils were positively affected by group work activities as was observed by one pupil who had to this to say:

Group work allowed us to explore different avenues of knowledge on living things and reasons why they are grouped in their respective kingdoms.

This was supported by another pupil who said that:

Only the introduction of group discussions and the contributions from my friends made me understand.

This view was held by another pupil who said that:

I understood everything through discussion of the groups by the pupils and the good explanations from the teacher.

\subsubsection{Negative effects of Group Work}

Despite the fact that pupils liked group work because they were free to ask their friends for clarification, some teachers thought that group work was usually not effective. One teacher expressed the following sentiment:

The groups were just too big. I did not divide them well.

Pupils still maintained that they were comfortable with group work as evidenced by the way one pupil reported: 
We don't understand everything when the teacher is explaining. We need to consult from friends in groups in order to understand.

Moreover, one pupil disagreed with the friends who were supporting the use of group work during lessons and had this to say:

In our group were just copying from the textbook without understanding the stages of mitosis

However, one teacher argued that:

During lecture method students are often passive because there is no mechanism to ensure that they are intellectually engaged with the material.

This view was supported by another pupil who said

Information tends to be forgotten easily when we just remain silently listening to our teacher.

\subsubsection{Negative Effects of Lecture Method}

Some teachers also had negative comments about the teacher explanation discourse pattern citing lack of feedback. This sentiment came from one teacher who said that:

The lecture method fails to provide teachers with feedback about the extent of pupil learning.

\subsubsection{Inadequate Teaching Aids}

The non-availability of teaching materials as well as their use in classrooms despite been inadequate had effects on the learning of pupils. One teacher had this to say:

The inadequate charts had an effect on pupils because charts were not as many as to meet all the learners. A lot of pupils were sharing one chart thereby clouding at one point.

Another teacher who accepted that teaching materials had an effect on learning had this to say:

I did not prepare enough specimens for the pupils to see so there was congestion as pupils clouded the few stations where specimens were displayed. Other pupils were simply asking their

friends without checking on the few specimens due to space of viewing the specimens on display.

\subsubsection{Poorly Drawn Charts}

Some pupils also observed that some charts were not good enough. One pupil had this to say:

The drawings on the charts were not very clear. We did not understand anything from the chart.

This shows that some teachers bring to class poorly prepared charts which end up confusing pupils.

\subsubsection{Fast Presentation of Lessons}

Fast presentation of lessons was identified as one of the effects of teacher presentation discourse pattern. This was reported by one pupil who said that:

The teacher was too fast for me as a result I did not understand the names of the living organisms clearly.

\subsubsection{Lack of Cooperation Among Pupils}

Other pupils attributed the lack of understanding to lack of cooperation among the pupils in their group work assignments. One pupil had this to say:

I failed to understand some of the things because of lack of cooperation and a little bit of noise in our class.

\subsubsection{Noise classrooms and overcrowding}

The classrooms were quite noise as was reported by the previous speaker who sighted lack of cooperation in groups. Other pupils attributed lack of understanding to overcrowding in classrooms as was observed by one pupil who said that:

There was too much overcrowding in the class and the teacher's explanations were not very clear. 


\subsubsection{Difficult Biological Terms}

Other pupils thought that biological terms were difficult to understand. This was reported by one pupil who said that:

The biological terms which the teacher used in today's lesson were difficult for me to understand.

Another pupil said that:

Most of us did not understand anything and we did not even participate in the lesson. The teacher was not even explaining some of the terms which we did not understand.

One teacher accepted this challenge of biological terms and had this to say:

This topic is very challenging, the words are difficult to pronounce. The names are difficult to pupils as a result some pupils did not see any sense in classification of living organisms.

Another pupil who was in support of the teachers view on the challenges of biological terms had this to say:

The terms are too difficult to pronounce even remembering is difficult.

Furthermore, due to the high number of biological names in classification of living organisms, some teachers tend to confuse information as was reported by one teacher who said that:

I mixed up ideas when I started the lesson. I only got courageous as the lesson progressed. I made some wrong explanations at first.

\subsubsection{Difficulties in Understanding Stages of Mitosis and Meiosis}

Teacher used group work to describe the stages of mitosis and meiosis. Some pupils still did not understand the stages of cell division. One pupil had this to say:

I cannot explain the stages unless. I spend a lot of time reading on my own. That is when I can describe the stages of cell division.

The stages of cell division starting from interphase to telophase confused a lot of pupils. This was reported by many pupils. Some of their views are as follows:

How to explain the stages of mitosis was difficult for me.

This was echoed by another pupil who said that:

I did not understand some of the stages of meiosis. I cannot even differentiate between the first meiotic division and second meiotic division.

\subsubsection{Non Clarification of Issues}

Some teachers fail to clarify issues in class leaving pupils wondering. This was observed by one pupil who said that:

The teacher did not clarify whether there are just two kingdoms namely plant and animal kingdom.

The teacher needed to clarify to the pupils that the syllabus only emphasised plants and animals and not any of these living organisms.

\subsubsection{Low Level Questions}

During the teacher led discourse pattern, low level questions were used by teachers. This was observed by one pupil who said that:

Our teacher asks simple questions which are not even found in past exam papers when he is teaching us.

\subsection{What can be Done to Improve the Teaching of Topics Perceived to Be Difficult in Biology in Order to Facilitate Pupils' Understanding?}

There are several ways of improving the teaching of topics perceived to be difficult in order to facilitate pupils' understanding. This is what respondents said could improve the teaching of topics perceived to be difficult in biology. 


\subsubsection{Motivation}

Some respondents proposed that there was need to develop interest in pupils in topics perceived to be challenging to learn, this was shown by one teacher who said that;

Pupils can only learn effectively if they are motivated to learn. Very little learning can occur if pupils are not motivated.

Motivation is the most important factor that teachers should target in order to improve learning. When pupils are motivated they pay attention, they begin working on tasks and even ask questions.

\subsubsection{Incorporation of Practical Activities}

Some respondents suggested that lessons perceived to be difficult should include practical activities.. This was observed by one teacher who said that:

I would make it more practical and allow pupils to make models of cells at each stage using plain papers, cotton threads and glue. I would also use videos on mitosis if found.

\subsubsection{Use of a Variety of Teaching Aids}

Some teachers supported the use of different teaching aids as was reported by one teacher who said that:

There was need to bring more teaching aids for pupils to see

Another teacher who was in support of the teaching aids also had this to say:

I would provide more charts and also put pupils in pairs to avoid a lot of pupils using one chart.

One teacher regretted having taught a lesson without practical examples and he had this to say:

I should have improved my lesson by providing good practical examples.

\subsubsection{Use of Pictures and Videos}

Other teachers supported the use of pictures and videos during lessons involving mitosis and meiosis. One teacher had this to say:

I would make sure that each pupil has a picture showing all the stages of mitosis.

The use of power point presentations was also mentioned by teachers and one had this to say:

I would give the pupils power point presentations on mitosis and meiosis because it was difficult for me to draw diagrams on the board.

\subsubsection{Use of Worksheets}

Other suggestions which came out from the teachers on the improvement of the teaching of topics perceived to be difficult in biology included the use of work sheets. One teacher had this to say:

I should prepare worksheets and reduce on the number of pupils in groups.

Pupils also echoed the use of videos in lessons. This came to light when one pupil said that:

We need to have videos of mitosis and not just stationery pictures

\subsubsection{Use of Practical Work}

Other pupils emphasised the use of practical work. This was reported by one pupil who said that:

We need more practical work and more specimens in our groups for us to see.

This idea was supported by another pupil who said that:

The groups should be reduced and more work sheets given to pupils.

One pupil was more particular with the diagrams drawn by teachers and had this to say:

Teachers must draw diagrams properly on mitosis which they give us in our groups to discuss. 


\subsubsection{Need for Field Trips}

Classification is more interesting when it is taught outside the classroom right among the organisms. This was reported by one pupil who said that:

We need to go out in the environment and watch for ourselves the feature of living organisms not just listening from our teacher.

Another pupil had this to say:

The teacher should bring real organisms to show us in the classroom during lessons on classification of living organisms

\subsubsection{Giving a Variety of Examples}

One pupil thought that the teacher brought out a lot of examples on classification of living organisms and had this to say:

The teacher should consider using only a manageable number of examples so that we can have time to master them rather than giving us a lot of examples on classification of living organisms. This tends to confuse us.

\subsubsection{Provide More Time}

Some pupils wanted more time to be allocated to the teaching of cell division. One pupil had this to say:

I need a lot of time just learning this topic for me to understand. This topic of mitosis is very challenging to me so the teacher should spend some good time teaching this topic.

This idea was also supported by another pupil who said that:

Mitosis should be taught more than once. The teacher should teach this topic again for some of us to understand.

\subsubsection{Give Work to Pupils to do Outside Lessons}

Some pupils were in support of the homework policy and one pupil had this to say:

The teacher should give us this work so that we go and do it from home and then we come and present our findings to our friends.

Another pupil had this to say on homework:

The teacher should just give me an assignment so that I can do research on my own.

\subsubsection{Peer Teaching}

Other pupils wanted their fellow pupils to explain to them some difficult aspects of the topic and one pupil had this to say:

I will be able to understand if my fellow pupil explains to me. I failed to understand the terms which the teacher was using.

This was supported by another pupil who said that:

I need somebody who has understood this topic to teach me

When asked how best they could learn mitosis some pupils suggested that they wanted discussions amongst themselves and one pupil had this to say:

We can only learn mitosis properly through discussions among ourselves.

\subsubsection{Changing of Teachers}

One pupil thought that they were so many in class and had this to say:

Learning can only improve in this class by reducing the number of pupils and also by changing the teacher.

Some pupils were not comfortable with their teachers. However, one pupil who was against changing the teacher had this to say: 
We as pupils we need to concentrate very much as the teacher is teaching we need to pay attention. We should not only blame the teacher for not understanding what he is teaching.

\subsubsection{Increase Time for Questions}

When one teacher was asked on how he would improve his lessons said that:

I would give them more time to ask questions about the topic as well as giving them work cards instead of writing on the board.

This simply indicates that teachers do not give their pupils chance to ask questions where they are not clear.

\section{Discussion on Classroom Discourse PatTerns}

The study established that teachers asked low level questions during their lessons and that pupils had very little opportunities to ask questions. The predominant mode of classroom talk during question and answer sessions was Triple A which is Ask, Answer, Accept orDouble A and then $\mathbf{R}$ which is Ask, Answer and Reject. Teachers could not clarify why the answer given by pupils was correct they simply accepted it to be correct and they never gave a reason to wrong answers provided by pupils, they simply rejected the answer. However, this method of teaching encouraged active participation of pupils in the classroom through exchange of ideas with the teacher, provided a forum for questions, feedback, and clarifications. If you teach a large class, you won't be able to answer every question aloud during class time. You should have a forum for your students to ask questions both inside and outside of class time.It was discovered in other lessons that despite the syllabus emphasising the diversity of algae, mosses, ferns, corniferous plants and angiosperms. Teachers only taught angiosperms. This was also seen under kingdom animalia where teachers had to ignore the arthropods and concentrated on the phylum chordata. It was very clear from the lessons observed that some teachers taught kingdoms which are not in the syllabus leaving important aspects of kingdom plantae and animalia which are in the syllabus.

The study also revealed that classification is not taught practically as a result pupils connect classification with a task of memorising a list of biological names. This is in line with ECZ (2016) where the chief marker reported that pupils fail to use scientific names of locally known plants and animals.

Pupils find it difficult to describe the stages of cell division. This confirms findings of an earlier study (Haambokoma, 2007). In this study pupils indicated that they were unable to master the various stages of mitosis and meiosis.

This is also supported by ECZ (2008) where the chief marker reported that many candidates failed to answer a question on meiosis. Even those who attempted to answer failed to bring out the actual events during meiosis which could cause each ovum to be genetically different from one another.

\subsection{Discussion on the Choice of Discourse Patterns}

The second research question was, 'how do teachers of biology arrive at the choice of discourse patterns they use for teaching topics perceived to be difficult in biology?'

The findings clearly show that choice of discourse patterns depends on a number of issues such as the non-availability of teaching and learning materials. Inadequate teaching resources contribute to ineffective teaching in secondary schools.

It is true that the amount of work to be covered also determines the choice of discourse patterns employed by teachers. Large volumes of work are properly covered by teacher explanation discourse where pupils have very little time to ask questions. Teachers held a view that group work was not appropriate for a lot of content which needs to be covered in a short period of time. Others argued that lecture method is very appropriate when the teacher wants to capture pupils' minds when introducing new concerts. This confirms findings from Ugwuadu (2011) who argued that the authoritative discourse pattern affords little or no interaction between the teacher and pupils during classroom activities. In addition, pupils are not allowed to share ideas and opinions with the teacher. The main task of the teacher is verbal presentation of facts and principles to pupils while pupils remain passive Teacher explanation discourse patterns are also used when difficult concepts are introduced to pupils. 
Other teachers who were against the lecture method argued that pupils learn properly if they are involved in the lesson such teachers were striving for methods which involved pupils such as discussion and question and answer sessions. Care was usually taken to control brighter pupils from monopolising the lessons and making other pupils passive.

Teachers also prefer methods where they link lessons to real- life examples. Field trips are preferred for the teaching of classification but they are not conducted because teachers feel that they waste a lot of time. In most cases teachers wanted to use methods they were very conversant with. They did not want to pick on methods where they had very little to implement. Many teachers opted for the group work where they gave pupils challenging work and went round the groups moderating the discussions to make learning successful.

In some instances teachers wanted methods which could involve a lot of pupils in the lesson. This is the reason why teachers wanted to use group work. Other teachers thought that during group work a lot of average pupils were assisted by above-average pupils. Still others thought that pupils could only be involved in the lesson during the teacher led discussions where the teacher directed which pupil to talk during the lesson thereby involving every pupil in the lesson.

Pupils held the view that teachers picked on methods where they had very little to do in the class. Pupils described this as laziness on the part of the teachers who liked using group work. This is particularly true because teachers chose methods which were less involving on their part. This was also seen when teachers were found without lesson plans such that it was difficult even to predict their line of action in the lesson. Lessons were usually haphazard and different unsuccessful methods of teaching were employed by the teacher.

\subsection{Discussion on Effects of Discourse Patterns on Pupils' Understanding}

The third research question was, 'What effects do these discourse patterns teachers use have on pupils' understanding of perceived difficult topics in biology?'

Findings have shown that different discourse patterns affect learning in many ways. Despite the successes of group work talked about by the teachers. Many pupils interviewed revealed that they were not doing anything meaningful in groups. They were usually doing other things other than the work they were given to do. Poorly planned group work attracts inappropriate group activities.

Group activities were usually designed by teachers who did not even have lesson plans and failed to find appropriate work to give pupils and pupils were just told to draw diagrams on mitosis. Pupils were usually left with no alternative but to just start copying everything from the few text books they had on their desks.

The study discovered that good introductions affected learning in a positive way and the use of various teaching aids in lessons to introduce aspects of living things by showing real life organisms brought about interest among pupils. However, the availability of specimens did not guarantee effective teaching. It was their skilful handling by the teacher that rendered these teaching aids useful in facilitating learning.

Group discussions also proved effective as was shown by pupils in their responses during the interview because they were encouraged to search for knowledge rather than the teacher monopolising the transmission of information to the pupils. Pupils were happy in groups because they were able to develop social skills through establishing friendships while working cooperatively in groups.

Pupils usually understood very little during teacher explanation discourse because teachers were merely focusing on dispensing rules, definitions and procedures for pupils to memorise without engaging pupils as primary participants. Teachers must realise that learning becomes effective when pupils are tasked to perform rather than just asked to remember some information.

The teacher explanation discourse made pupils obtain information from the teacher without building their engagement levels with the topics taught. The frequent use of the teacher explanation discourse was observed as teachers wanted to complete the syllabus without minding whether pupils were following or not. Teachers were rushing to complete the syllabus as a result most of them were very fast in their presentations making it difficult for the pupils to follow the lesson. 
The findings indicated that inadequate teaching and learning materials hinders effective teaching and learning. This situation often made it difficult for teachers to take pupils through practical work. Moreover, classes were large and this made discussion and practicals difficult.

The numerous biological terms under the topic of classification of living organisms impacted negatively on the pupils' learning. Pupils believed that the topic was difficult because they failed to memorise the numerous biological terms involved. Mastering stages of mitosis and meiosis was difficult among pupils because lessons involved rote learning with very little attention to securing pupil understanding. This is in line with Schmid and Teraro (1990) who reported that biology is so difficult to teach and learn because it consists of a myriad of unfamiliar concepts involving complex relations. They identified rote learning as the school's favoured approach to teaching unfamiliar material. However, rote learning fails in the face of complex interactions involved in biology. This also confirms findings of Tekkaya, Ozkan and Sungur (2001) who reported that the difficulties in learning mitosis and meiosis can be attributed mainly to terminology and abstract level of concepts. The biological terminology used in mitosis and meiosis is very complicated and includes many terms such as chromosomes, genes, alleles, chromatids and DNA. Pupils mix these terms and generally memorise these concepts and forget them after some time.

Teachers usually failed to clarify issues on the kingdoms of living organisms. Most teachers taught the topic without the guide of the syllabus. They taught materials which were not found in the syllabus such as kingdom Protista, Fungi and Monera. However, those who followed the syllabus failed to explain to pupils that there were only two kingdoms in the syllabus which they were supposed to teach out of the five kingdoms. The syllabus expected teachers to teach the kingdom Animalia and kingdom Plantae.

Using the transaction model developed by Huitt (1995) this study identified effects of discourse patterns based on the teacher pupil relationships and classroom activities.

\subsection{Discussion on the Improvement of Teaching Topics Perceived to be Difficult In Biology}

The fourth research question was, 'What can be done to improve the teaching of topics perceived to be difficult in biology in order to facilitate pupils 'understanding?'

Evidence from the findings indicated that without motivation from the teachers to the pupils effective learning cannot take place. A motivated class even participates in the lesson by answering as well as asking questions.

Findings indicated that for a lesson to be successful it must incorporate the practical component. Teachers should make available models made out of simple materials. Teachers sometimes fail to improvise teaching aids and models when they can easily make their own and make teaching interesting.

The use of pictures and videos was supported by both teachers and pupils. Other teachers even hoped to use power point presentations during their lessons to get the attention of pupils. Some pupils were even against stationery pictures and wanted moving pictures such as short documentaries of mitosis and meiosis.

Too much work in a short period of time was one of the concerns raised by pupils. They thought that the teacher offloaded a lot of examples in a short time thereby making it difficult for them to remember something. Another alternative which came from the pupils was that there was need to give a lot of time to these topics of mitosis and meiosis. Pupils wanted their teachers to spend a lot of time on these perceived difficult topics. Some pupils believed that for them to understand the topic the teacher should teach more than once.This confirms findings from Reece and Walker (1997) who argued that when lessons are presented in a very fast manner pupils fail to follow the lesson therefore learning cannot take place. Usually many teachers of biology would like to present lessons very fast so that they can cover the wide biology syllabus.

Still some pupils maintained that they would only understand classification of living organisms if they listen to their fellow pupils explain the topic to them. Pupils really expected their fellow pupils to teach them after the teacher had taught the lesson. Pupil discussions were very much liked by the 
pupils because they were expecting to get a lot of information from their friends. Slower learners benefited very much because they were able to seek clarification from their peers.

Some teachers suggested that they needed to give pupils more time to ask questions and seek clarification on issues where they were not clear. This corroborates with Beccles (2012) who advised that teachers need to use questions to elicit student thinking, regularly invite questions from students and encourage responses from students. Beccles further advised that teacher questions need to stress remember, understand, apply, analyse, evaluate and create cognitive processes as well as factual, conceptual, procedural information and meta-cognitive knowledge dimensions. Beccles observed that the quality of student's answers and thinking is a reflection of teacher questions, therefore, the cognitive processes and knowledge dimensions need to be appropriately stressed. It was also suggested that work cards be given to pupils instead of teachers giving work to pupils on the board.

\section{CONCLUSION}

The study has revealed discourse patterns used by teachers when teaching aspects of classification, mitosis and meiosis andmost importantly the findings have shown that the choice of discourse patterns was guided by many factors such as the availability of teaching and learning materials, the instructional materials to be taught to pupils, the quality of the learners, the preparation of the teacher and the number of pupils in the class. The study established that there was no single method which was best suited for all the topics and for all the teachers and pupils.

Findings have shown that pupils interpersonal skills were enhanced by the pupil to pupil discourse pattern were pupils tackled problems together and made presentations on the work given to them by teachers. Moreover, it was clear from the findings that teacher explanations impacted negatively on the pupils' retention of knowledge because pupils remained passive without any chance of asking questions.

In addition the findings have shown that teachers aspire to have their pupils learn. However, the learning styles of pupils differed therefore it was not easy to satisfy all the pupils with one method of teaching. The study found that teachers employed different teaching methods to satisfy the different learning styles among the pupils.

Furthermore the study revealed that teachers try by all means to incorporate the pupil centred methods by involving pupils in group work. These group work activities affected learning in many ways. Group work activities were poorly supervised as a result pupils ended up benefiting very little from their groups. However, some groups which were organised and supervised properly by the teachers benefited the pupils very much by providing a platform where pupils exchanged and shared ideas.

The study established that teachers asked low level questions during their lessons and that pupils had very little opportunities to ask questions.

\section{RECOMMENDATIONS}

The findings of the study have revealed the discourse patterns used by teachers when teaching topics perceived to be difficult in biology. Therefore, in view of the findings above, the following recommendations are made;

1. Teachers should combine the three discourse patterns namely teacher explanation, teacher led and pupil to pupil discourse patterns when teaching biology because these patterns proved effective when used together.

2. Teachers should avoid using one discourse pattern during lessons on topics perceived to be difficult.

3. Workshops and seminars should be organised for teachers to enable them acquire skills of teacher explanation, teacher led and pupil to pupil discourse patterns for teaching biology.

\section{ACKNOWLEDGMENTS}

This study could not have been possible without the tireless efforts of my well informed supervisors Dr Haambokoma. C and Dr Nachiyunde. $K$ 


\section{REFERENCES}

[1] Abimbola, I.O. (1998) "Teachers perception of important and difficult biology contents" Journal of functional education, 1(1), 10-21.

[2] Beccles, C. (2012).Science teaching, classroom discussion and contexts in junior high schools in Ghana. Ph.D. Thesis. Graduate school for international Development and co-operation: Hiroshima University.

[3] Creswell, J.W. (2003).Research Design: qualitative, quantitative and mixed methods approaches. Thousand Oaks, California: SAGE Publications.

[4] Curriculum Development Centre CDC. (2000).High school biology syllabus. Lusaka: Ministry of Education.

[5] Chifwa, J. (2015). The teaching of Genetics in selected secondary schools in Kitwe District, Zambia. Med (Science Education) Thesis, Lusaka: UNZA.

[6] Chocha, S.E, Namayanga, K.C., \& Ndhlovu, H.G. (2014). Teaching Science Practically: An assessment of Teacher competences on O-Level biology practical work in Zambia.Policy, Zambia Journal of Teacher professional growth. 2(1) 26-38.

[7] Cimer, A. (2012). What makes biology learning difficult and effective: Student's views.Education Research and Reviews. 7(3), 61-71.

[8] Examination council of Zambia. (2004). Examination performance review, Lusaka: ECZ.

[9] Examination council of Zambia. (2008). Examination performance review, Lusaka: ECZ.

[10] Examination council of Zambia. (2016). Examination performance review, Lusaka: ECZ.

[11] Haambokoma,C. Nkata, B. Kostyuk, V.S. Chabalengula, V. Mbewe, S. Tabakamulamu, M. Ndhlovu, Z.B. Mushanga, R. and Nthani, D. (2002). Strengthening of Mathematics and Science Education in Zambian Secondary schools: Baseline Study, Lusaka: J.I.C.A.

[12] Haambokoma, C. (2007). Errors pupils make in the biology practical test of the school certificate examination. Proceedings of the $15^{\text {th }}$ annual conference of the southern African Association for research in mathematics, science and technology education, 1.

[13] Kombo, D. K., \& Tromp, D. L. A. (2006). Proposal and thesis writing. An introduction,

[14] Nairobi, Paulings Publications Africa.

[15] Louis. C, Lawrence, M \& Keith, M. (2000).Research Methods in Education. London: RoutledgeFalmer.

[16] Merriam, B.S. (1998). Qualitative research and case study applications in education. San Francisco: Jossey-Bass Inc. publishers.

[17] Ministry of Education. (1994). Baseline study for the AIMS project, Lusaka: MoE.

[18] Ministry of Education. (1996). Educating our future, Lusaka: Ministry of Education.

[19] Mudenda, V. (2008). Zambian grade twelve pupils experiences of biology practical work during school certificate examinations. The case for Kabwe high school; and un published M E D (Science Education) Thesis, Lusaka: University of Zambia.

[20] Musonda, M. (2013). Topics in biology perceived as difficult to learn; Un published MED (Science Education) Thesis, Lusaka: University of Zambia.

[21] PEO, Mansa. (2016). Grade 12 examination analysis, Mansa: PEO.

[22] PEO, Mansa. (2017). Grade 12 examination analysis, Mansa: PEO.

[23] Reece, I., \& Walker, S. (1997).Teaching, training and learning, third edition, Sunderland: business education publishers Ltd.

[24] Ross. P. (2011).Challenges in teaching biology. Retrieved on $7^{\text {th }}$ April 2016 from https://talking. teaching.wordpress.com

[25] Ugwuadu, O.R. (2011).Effects of discourse patterns on students' achievement and interests in biology. A thesis submitted to the Department of Science Education, Faculty of Education, University of Nigeria: Nsukka. 


\section{AUTHORS' BIOGRAPHY}

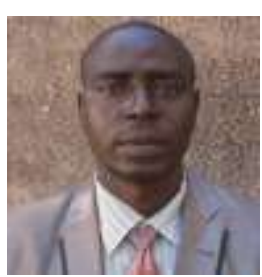

Mr. Kambi Manda, is a Ph.D candidate in Science Education at the University of Zambia in the Department of Mathematics and Science Education. Currently he is Head of Department for Natural Sciences at Lubwe Secondary School in Luapula Province of Zambia and works as a part time Lecturer at Chalimbana University.

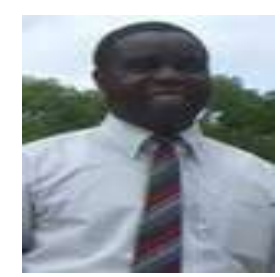

Dr. Christopher Haambokoma, is a senior Lecturer of biology education at the University of Zambia in the Department of Mathematics and science Education. He holds a Ph.D in Science Education from the Norwegian University of life sciences.

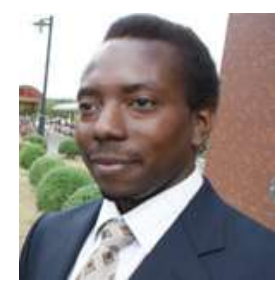

Dr. Kabunga Nachiyunde, is a lecturer of Chemistry Education at the University of Zambia in the Department of Mathematics and Science Education. He holds a Ph.D in Chemistry Education from Hiroshima University in Japan.

Citation: Kambi, Manda et al. "Discourse Patterns of Lessons on Topics Perceived to be Difficult in Biology at Selected Secondary Schools in Luapula Province of Zambia." International Journal of Humanities Social Sciences and Education (IJHSSE), vol 4, no. 11, 2017, pp. 26-42. doi:http://dx.doi.org/10.20431/23490381.0411004.

Copyright: () 2017 Authors. This is an open-access article distributed under the terms of the Creative Commons Attribution License, which permits unrestricted use, distribution, and reproduction in any medium, provided the original author and source are credited. 